DOI 10.31558/2307-2318.2019.1.2

УДК 331.108

Дороніна О.А., доктор економічних наук, професор, Донецький національний університет імені Василя Стуса

Рязанов М.Р., завідувач міжкафедральної лабораторії інформаційно-організаційного забезпечення наукової діяльності та підготовки до друку наукових видань, Донецький національний університет імені Василя Стуса

\title{
КАДРОВА ПОЛІТИКА ЯК ІНСТРУМЕНТ СТРАТЕГІЧНОГО РОЗВИТКУ ЗАКЛАДУ ВИЩОЇ ОСВІТИ
}

У статті обгрунтовано роль кадрової політики як провідного інструменту стратегічного розвитку закладу вищої освіти. Запропоновано авторській підхід до визначення кадрової політики 3ВО, окреслено її мету, об'єкт та принципи. Досліджено особливості формування кадрової політики у закладах вищої освіти. Визначено ключові напрями кадрової політики ЗВО (постійний розвиток персоналу, гідне матеріальне стимулювання та забезпечення психологічного комфорту) та запропоновано низку рекомендацій щодо реалізації кожного з них. Окреслено можливі позитивні ефекти від формування та реалізації раціональної кадрової політики як для 3ВО, так і для кожного працівника.

Ключові слова: кадрова політика, заклад вищої освіти, людські ресурси, управління персоналом, стратегічний розвиток.

\section{Доронина О.А., Рязанов Н.Р.}

\section{КАДРОВАЯ ПОЛИТИКА КАК ИНСТРУМЕНТ \\ СТРАТЕГИЧЕСКОГО РАЗВИТИЯ ВЫСШЕГО УЧЕБНОГО ЗАВЕДЕНИЯ}

В статье обоснована роль кадровой политики как ведущего инструмента стратегического развития высшего учебного заведения. Предложено авторский подход к определению кадровой политики ВУЗа, определены её цели, объект и принципы. Исследованы особенности формирования кадровой политики в учреждениях высшего образования. Определены ключевые направления кадровой политики высшего учебного заведения (постоянное развитие персонала, достойное материальное стимулирование и обеспечение психологического комфорта) и предложен ряд рекомендаций по реализации каждого из этих направлений. Определены возможные положительные эффекты от формирования и реализации рациональной кадровой политики как для ВУЗа, так и для каждого его сотрудника.

Ключевые слова: кадровая политика, высшее учебное заведение, человеческие ресурсы, управление персоналом, стратегическое развитие.

\section{Doronina O., Riazanov M.}

\section{PERSONNEL POLICY AS A TOOL FOR STRATEGIC}

\section{DEVELOPMENT OF A HIGHER EDUCATION INSTITUTION}

The article reviews the role of personnel policy as a leading tool for strategic development of a higher education institution. The author's approach to the definition of personnel policy of a higher education institution has been offered, and its purpose, object and principles have been outlined. The features of personnel policy formation in higher education institutions have been researched. The key directions of higher education institution personnel policy (continuous personnel development, decent material incentives and psychological comfort provision) have been determined, while a number of recommendations for the 
implementation of each of these approaches have been offered. Possible positive effects of reasonable personnel policy formation and implementation for both higher education institutions and their employees have been outlined.

Key words: personnel policy, higher education institution, human resources, human resources management, strategic development.

Постановка проблеми. У сучасних реаліях формування інформаційного суспільства $є$ незаперечною провідна роль сучасних та міждисциплінарних знань, як ключового ресурсу суспільно-економічного розвитку. Саме володіння якісним та актуальним знанням $є$ одним 3 найважливіших факторів конкурентоспроможності працівника на ринку праці. У таких умовах перед закладами вищої освіти (3ВО) постає достатньо складне завдання - забезпечувати населення країни такими знаннями та компетенціями, що відповідають світовим та національним інноваційним трендам. Тобто, саме 3ВО є осередком становлення та розвитку економіки знань. Беззаперечним $\epsilon$ твердження, що виконувати цю функцію заклади вищої освіти можуть лише за умов формування відповідного кадрового складу викладачів та науковців, його розвитку та стимулювання, на забезпечення чого й має бути орієнтована їхня кадрова політика.

Аналіз останніх досліджень та публікацій. Питанням формування кадрової політики організацій займалися такі науковці, як Батеман Х., Бєляцький М.П., Белякова B.В., Борщ B.І., Гончаров М.А., Дмитренко Г.А., Карташова Л.В., Колпаков В.М., Крушельницька О.В., Лабаджян М.Г., МакАдам К., Мельничук Д.Г., Одєгов Ю.Г., Сельцовський П.А, Стрехова С.В. та багато інших. Однак, особливості формування кадрової політики ЗВО, що обумовлені специфікою їх діяльності як організаційних утворень у науковій літературі висвітлені недостатньо, що зумовлює актуальність дослідження.

Метою дослідження є тлумачення сутності кадрової політики ЗВО та визначення особливостей іï формування в системі стратегічних пріоритетів розвитку.

Викладення основного матеріалу. Вивчення літературних джерел за тематикою дослідження показує, що погляди зарубіжних та вітчизняних науковців на визначення сутності категорії «кадрова політика» суттєво різняться. Найбільш змістовні з існуючих підходів до тлумачення досліджуваного поняття наведено у таблиці 1.

Погляди науковців на визначення поняття «кадрова політика»

\begin{tabular}{|c|c|}
\hline Джерело & Визначення \\
\hline $\begin{array}{l}\text { Батеман X., } \\
\text { МакАдам К. } \\
{[1, \text { с. } 199]}\end{array}$ & $\begin{array}{l}\text { Кадрова політика - низка особливих правил, або рекомендацій, що } \\
\text { визначають шляхи вирішення питань, пов’язаних з персоналом організацій }\end{array}$ \\
\hline $\begin{array}{l}\text { Бєляцький М.П. } \\
{[2, \text { с. } 15]}\end{array}$ & $\begin{array}{l}\text { Кадрова політика - принципи, цілі та стратегії в сфері роботи з персоналом, } \\
\text { на які орієнтовані всі заходи щодо роботи з кадрами }\end{array}$ \\
\hline $\begin{array}{l}\text { Крушельницька О.В., } \\
\text { Мельничук Д.П. [9, с. 42] }\end{array}$ & $\begin{array}{l}\text { Кадрова політика - сукупність принципів, методів, форм організаційного } \\
\text { механізму з формування, відтворення, розвитку та використання персоналу, } \\
\text { створення оптимальних умов праці, його мотивації та стимулювання }\end{array}$ \\
\hline $\begin{array}{l}\text { Одєгов Ю.Г., } \\
\text { Лабаджян М.Г. } \\
{[8, \text { с. } 18]}\end{array}$ & $\begin{array}{l}\text { Кадрова політика - генеральний напрямок кадрової роботи, що містить } \\
\text { сукупність принципів, методів, форм організаційного механізму по } \\
\text { виробленню цілей і задач, спрямованих на збереження, укріплення та } \\
\text { розвиток кадрового потенціалу, створення високопродуктивног, } \\
\text { згуртованого колективу, здатного своєчасно реагувати на мінливі вимоги } \\
\text { ринку }\end{array}$ \\
\hline $\begin{array}{l}\text { Стрехова С. В. } \\
{[10, \text { с. } 67]}\end{array}$ & $\begin{array}{l}\text { Кадрова політика - сукупність принципів, методів, форм, заходів і процедур } \\
\text { iз формування, відтворення, вдосконалення та використання персоналу, } \\
\text { створення оптимальних умов праці, ії мотивації та стимулювання }\end{array}$ \\
\hline
\end{tabular}


Узагальнення вищевикладених підходів дозволяє сформулювати визначення сутності кадрової політики для такого специфічного типу організацій як ЗВО. Пропонуємо кадрову політику $3 B O$ розглядати як систему інструментів, методів та принципів ефективного управління людськими ресурсами 3ВО, що є засобом реалізації його стратегії та спрямована на забезпечення конкурентоспроможності закладу на ринку освітніх послуг.

Формування та адміністрування ефективної кадрової політики ЗВО можливо лише при наявності окресленої, з урахуванням специфіки діяльності, стратегії розвитку. Так наприклад, залежно від того, як будуть різнитися стратегії на ринку освітніх послуг класичного університету та медичної академії - будуть визначатися суттєві відмінності їх кадрових політик. Саме чітке усвідомлення специфіки, стратегічних напрямів та пріоритетів закладу дає змогу раціонально оцінювати його людські ресурси, планувати та реалізовувати усі аспекти кадрової роботи.

Метою кадрової політики сучасного закладу вищої освіти, на нашу думку, має бути створення системи управління людськими ресурсами, спрямованої на залучення працівників високого професійного рівня та таких, які володіють сучасними просвітницько-дослідними компетенціями, збереження таких працівників та їх розвиток, забезпечення гідними умовами праці й комфортним кліматом у колективі, що сприятиме успішній реалізації стратегії закладу.

Більшість науковців, погляди яких узагальнено у табл. 1, визначають у якості об'єкту кадрової політики 3ВО персонал. На наш погляд, у цій ролі мають розглядатися людські ресурси, як категорія, що підкреслює провідну роль працівників у забезпеченні конкурентоспроможності установи на ринку освітніх послуг.

Будь-яка організація має формувати свою кадрову політику за певними принципами. Дослідження напрацювань сучасних науковців у сфері економіки та менеджменту дозволяє визначити різні підходи до їх ідентифікації (табл. 2).

Таблиця 2

Сучасні підходи до визначення принципів кадрової політики

\begin{tabular}{|l|l|}
\hline \multicolumn{1}{|c|}{ Джерело } & \multicolumn{1}{|c|}{ Запропоновані принципи } \\
\hline $\begin{array}{l}\text { Борщ В.І., } \\
\text { Белякова В.В. [3, с. 180] }\end{array}$ & $\begin{array}{l}\text { стратегічна спрямованість; } \\
\text { системність; } \\
\text { послідовність; } \\
\text { гнучкість; }\end{array}$ \\
\hline Гончаров М.А. [4, с. 88] & $\begin{array}{l}\text { цілеспрямованість; } \\
\text { функціональний підхід; } \\
\text { комплексність; }\end{array}$ \\
\hline $\begin{array}{l}\text { Колпаков В.М., } \\
\text { Дмитренко Г.А. [5, с. 216] }\end{array}$ & $\begin{array}{l}\text { базисні: науковість, моральність, законність, демократизм, } \\
\text { наступність, змінюваність, конкетно-історичний підхід; } \\
\text { специфічні: відкритість; гласність; добір персоналу за діловими, } \\
\text { діяльностими служороральними якостями; соціальний контроль за }\end{array}$ \\
\hline $\begin{array}{l}\text { ддсгов Ю.Г., тощо. } \\
\text { Карташова Л.В. [7,с. 39] }\end{array}$ & $\begin{array}{l}\text { демократизм в управлінні та готовність до співробітництва; } \\
\text { знання окремих людей та їх потреб, врахування інтересів індивіда } \\
\text { справедливість, дотримання рівності та послідовність. }\end{array}$ \\
\hline
\end{tabular}


Слід зазначити, що при всій своїй справедливості, викладені принципи повністю не відображають реалій формування кадрової політики для такої специфічної організації як заклади вищої освіти. У зв'язку з цим, пропонуємо власне бачення набору принципів, на яких має грунтуватися кадрова політика сучасного ЗВО (рис.1).

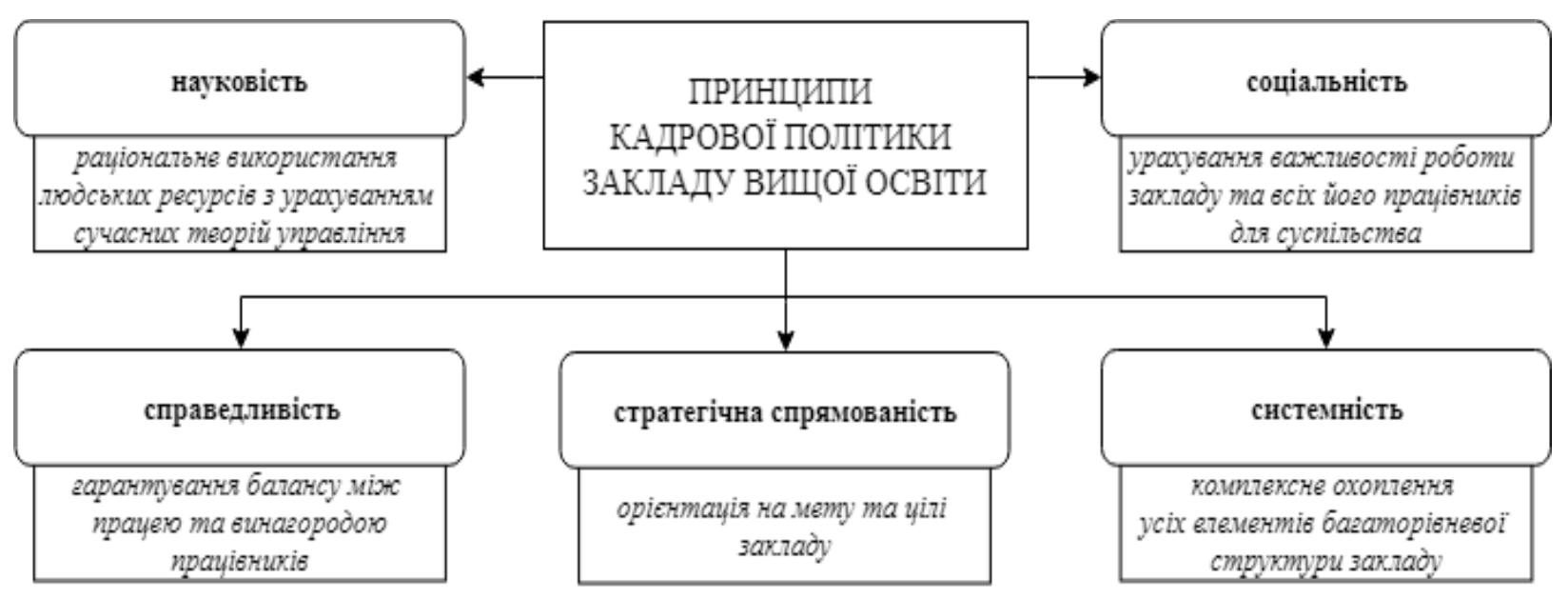

*складено авторами

Специфіка діяльності ЗВО призводить до певних особливостей формування його кадрової політики. По-перше, безумовно, це фінансова обмеженість. На сьогоднішній день, в Україні освіта - це не та галузь, що приносить значні прибутки. Пов'язано це, перед усім, з низькими рівнем доходів населення та пострадянським стереотипом, про те, що освіта має бути безкоштовною. Відсутність достатньої кількості фінансових ресурсів суттєво обмежує ресурсне забезпечення кадрової політики - неможливо гідно винагороджувати працівників, забезпечувати їх достатнім соціальним пакетом та можливостями професійного розвитку.

По-друге, це високі вимоги до професійності працівників, зокрема професорськовикладацького складу, зумовлені характером наукової та педагогічної діяльності.

По-третє, це гостра необхідність постійного підвищення кваліфікації працівників. Це викликано тенденцією до «старіння знань», яка притаманна сучасному суспільству. Під впливом наукового прогресу змінюється картина світу, на заміну старим теоріям та концепціям - приходять нові. Фахівці вищої освіти ж завжди мають володіти актуальними знаннями у своїй сфері - бо саме це є запорукою підготовки компетентних кадрів, які будуть готові до реалій ринку праці.

В таких умовах, вважаємо, що основні заходи кадрової політики сучасного українського ЗВО мають бути сконцентровані у трьох ключових напрямах:

постійний розвиток персоналу;

гідне матеріальне стимулювання;

забезпечення психологічного комфорту.

Зупинимося більш детально на їх змісті та особливостях практичної реалізації у 3BO.

Розвиток персоналу. Сьогодні в Україні склалася ситуація, коли ЗВО, які за сутністю своєю $\epsilon$ «постачальниками» освітніх послуг, здебільшого, виявилися неспроможні якісно організувати навчання та розвиток власного персоналу. Існуюча система підвищення кваліфікації в окремих випадках є формальністю та відповідно, 
нездатна якісно забезпечити розвиток кадрового потенціалу закладу вищої освіти. Зрозуміло, що в таких умовах перш за все страждає конкурентоспроможність українських 3ВО. Інструментами для вирішення цієї проблеми можуть стати сучасні HRтехнології: асесмент-центр, коуч-методики, талант-менеджмент та інші.

Матеріальне стимулювання. Базовою умовою удосконалення кадрової політики, на наш погляд, є забезпечення гідного рівня заробітної плати для працівників: якщо не вирішене дане питання, то весь програмний комплекс кадрових заходів просто не матиме сенсу. Саме рівень заробітної плати характеризує організацію як соціальновідповідального роботодавця. Потрібно взяти до уваги, що оскільки більшість ЗВО є бюджетними установами, то збільшення фонду оплати праці можливо за рахунок використання доходів, отриманих від платної освітньої діяльності, наукових i госпдоговірних проектів.

Особливо актуальним вбачається питання мотивації працівників закладів вищої освіти до майбутніх результатів. Рейтингова система оцінки персоналу, яка практикується у багатьох українських ЗВО, є за своєю природою «ретроспективною» та не може повноцінно вирішувати цю проблему. Новим рішенням може стати створення внутрішніх університетських фондів, що будуть фінансувати проекти за пріоритетними напрямами освітньої, наукової та інноваційної діяльності закладу. Механізм полягає у наданні кожному працівникові можливості розробити проект та отримати фінансування на його реалізацію за рахунок фонду. Успішне ж завершення проекту передбачає преміювання робочої групи виконавців. Впровадження такої моделі матеріального стимулювання дозволить мотивувати працівників до професійного та особистісного зростання.

Психологічний комфорт. Беззаперечно, важливим напрямом кадрової політики будь-якого сучасного закладу вищої освіти має бути забезпечення психологічного комфорту його працівників. Це зумовлено загрозою професійного вигорання - типової проблеми для педагогічних працівників, як фахівців, що мають постійно комунікувати 3 великою кількістю людей, працювати зі значними масивами інформації та регулярно вдосконалювати свої знання. Статична інтелектуальна напруга несе негативний вплив на психологічний стан, тому для збереження здоров'я, психічної стійкості, надійності і професійного довголіття фахівця необхідні системні заходи протидії вигоранню. Комплекс таких заходів для ЗВО запропоновано у таблиці 3.

Таблиця 3

Комплекс заходів із забезпечення психологічного комфорту працівників 3ВО

\begin{tabular}{|l|l|}
\hline \multicolumn{1}{|c|}{ Напрям } & \multicolumn{1}{|c|}{ Заходи } \\
\hline $\begin{array}{l}\text { 1. Забезпечення психологічної } \\
\text { стабільності працівників }\end{array}$ & $\begin{array}{l}\text { - тренінги по самонавчанню; } \\
\text { - ознайомлення з базовим принципам ситуаційного контролю; } \\
\text { - майстер-класи з розширення поведінкового репертуару; } \\
\text { - анкетування щодо задоволеності умовами праці. }\end{array}$ \\
\hline $\begin{array}{l}\text { 2. Зниження ризиків } \\
\begin{array}{l}\text { професійного вигорання } \\
\text { працівників }\end{array}\end{array} \begin{array}{l}\text { - моніторинг когнітивної оцінки; } \\
\text { працівників; } \\
\text { - аналіз психологічного клімату у структурних підрозділах } \\
\text { університету; }\end{array}$ \\
\hline $\begin{array}{l}\text { 3. Організація антистресового } \\
\text { навчання працівників }\end{array}$ & $\begin{array}{l}\text { - лекції з психології стресу; } \\
\text { - тренінги з емоційного контролю; } \\
\text { - дослідження стрес-факторів за структурними підрозділами. }\end{array}$ \\
\hline
\end{tabular}


Викладений вище комплекс заходів дозволить нівелювати негативний вплив на психологічний стан працівників установи, що позитивно відобразиться на їх працездатності, знизить плинність кадрів та в цілому підвищить лояльність до ЗВО. Як результат практичної реалізації виокремлених пріоритетів кадрової політики - у навчальному закладі може бути сформована раціональна, з точки зору забезпечення стратегічного розвитку закладу та задоволення інтересів працівників, кадрова політика.

Формування зваженої та раціональної кадрової політики несе низку корисних ефектів, як для установи в цілому, так і для кожного окремого працівника (табл. 4).

Очікувані ефекти від формування та реалізації раціональної кадрової політики

\begin{tabular}{|l|l|}
\hline \multicolumn{1}{|c|}{ ДЛЯ ЗВО } & \multicolumn{1}{|c|}{ ДЛЯ ПРАЦІВНИКІВ } \\
\hline - сприяння закріпленню «кадрового ядра»; & - поліпшення умов праці; \\
- стимулювання підвищення ефективності & - сприяння професійному розвитку; \\
професійної діяльності кадрів; & - створення нових можливостей для \\
- підвищення ефективності використання & самореалізації; \\
фонду оплати праці & - забезпечення комфортного психологічного \\
- зниження плинності кадрів; & клімату; \\
- підвищення престижу закладу в якості & - отримання нових можливостей для \\
роботодавця; & збільшення рівня своєї заробітної плати; \\
- створення сприятливого клімату для & - створення нових каналів для комунікацій 3 \\
генерації інноваційних ідей працівниками; & керівництвом закладу; \\
- зростання середнього рівня лояльності & - зниження ризиків професійного \\
персоналу; & вигорання \\
- оптимізація мотиваційної системи & \\
\hline
\end{tabular}

Висновки. У сучасних умовах, ЗВО може бути конкурентним лише за умов ефективного та раціонального управління людськими ресурсами, якісним інструментом якого може стати кадрова політика. Специфіка діяльності накладає певні обмеження та нетипові вимоги щодо кадрової роботи у ЗВО. Формування кадрової політики з урахуванням представлених рекомендацій сприятиме забезпеченню конкурентоспроможності закладу на ринку праці, його розвитку та досягненню стратегічних цілей.

\section{СПИСОК ВИКОРИСТАНИХ ДЖЕРЕЛ}

1. Bateman H. McAdam K. Dictionary of Human Resource and Personnel Management. London: A\&C Black Publishers, 2006. 199 p.

2. Беляцкий Н. П. Управление человеческими ресурсами (HRM): учеб.-метод. пособие. Мн.: ФУАинформ, 2006. 320 с.

3. Борщ В. І., Белякова В.В. Формування і реалізація кадрової політики на підприємствах України. Ринкова економіка: сучасна теорія і практика управління. 2017. Том 16. №3 (37). C. 175-187.

4. Гончаров М.А. Основы менеджмента в образовании. М.: КНОРУС, 2008. 480 с.

5. Колпаков В.М., Дмитренко Г.А. Стратегический кадровый менеджмент: учеб. пособ. Ч.1. Київ: МАУП, 2002. 280 с.

6. Крушельницька О.В., Мельничук Д.П. Управління персоналом: навч. посіб. Київ: Кондор, 2005. 308 с.

7. Одегов Ю.Г., Карташова Л.В. Управление персоналом, оценка эффективности: учеб. пособ. для вузов. М.: Экзамен, 2002. 256 с.

8. Одегов Ю.Г., Лабаджян М.Г. Кадровая политика и кадровое планирование: учебник для вузов. М.: Издательство Юрайт, 2014. 444 с.

9. Стрехова С. В. Кадрова політика: важелі впливу на ефективність, механізми та інструменти реалізації. Економічний часопис XXI. 2012. № 3-4. С. 66-70. 